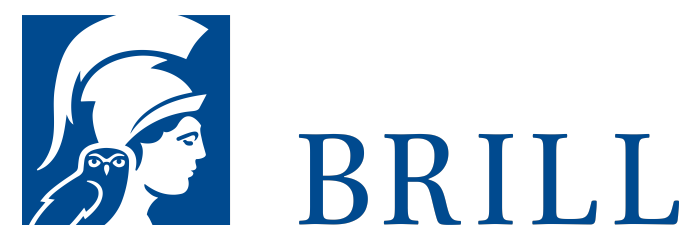

\title{
Gerechtigkeit in der modernen Arbeitsgesellschaft und Tarifautonomie
}

\author{
Authors: Katholische Sozialwissenschaftliche and \\ Arnd Küppers
}

Das deutsche Konsensmodell Soziale Marktwirtschaft ist in die Kritik geraten und mit ihm auch zwei seiner Hauptakteure: die Sozialpartner, Gewerkschaften und Arbeitgeberverbände. Ihnen wird der Vorwurf gemacht, in ihren Tarif-abschlüssen Verträge zu Lasten Dritter zu schließen - zu Lasten vor allem der Arbeitslosen und damit auf Kosten des Gemeinwohls. Diesem Vorwurf geht die Untersuchung nach. Sie nimmt dazu nicht nur die Geschichte und die aktuelle Gestalt der Tarifautonomie in den Blick, sondern fragt auch nach den Strukturen der modernen Arbeitsgesellschaft, vor allem den Gründen und Folgen des drängenden Problems der Massenarbeitslosigkeit. Unter der genuin sozial- ethischen Perspektive der Beteiligungsgerechtigkeit wird die Tarifautonomie gegen Fundamentalkritik verteidigt und die Diskussion über eine Reform des Tarifrechts bzw. eine Flexibilisierung der Tarifpolitik differenziert beurteilt.

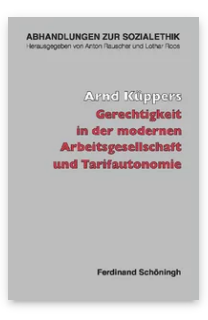

Pages: 544

Seiten

Language:

German

Subjects:

General,

Theology and

World

Christianity

Publisher: Brill |

Schöningh

Series:

Abhandlungen

zur Sozialethik,

Volume: 50

E-Book (PDF)

Released online:

o3 Feb 2020

ISBN: 978-3-

657-765०7-2

List price

USD $\$ 120.00$

Paperback

Publication date:

2o Feb 2008

ISBN: 978-3-

506-76507-9

List price

USD $\$ 120.00$ 
For more information see brill.com

Order information: Order online at brill.com +44330 333 0049 | customerservices@brill.com Submission information: brill.com/authors

Titles published by Brill | Fink, Brill | mentis or Brill | Schöningh: +49(o)715413279216| brill@brocom.de 